\title{
Selected bibliography on labor in Japan
}

\author{
Christopher Gerteis* \\ Creighton University, Omaha, Nebraska, USA
}

A senior American historian once told me that there were hardly any books on Japanese labor. His perception was understandable; indeed, there have been far too few English language books on labor and the working-class in Japan. Yet, I was chagrined to discover that he, along with many other labor historians, have based their understanding of Japan on a very small number of books published in the 1980s.

This selected bibliography, organized in reverse chronology, lists no books published earlier than 1990. Regrettably, the two dozen-plus books listed still reflect the majority of English language scholarship, and the only way to get a good bead on the field still is to read the Japanese literature. Years of intensive language study not withstanding - a path that I strongly encourage all current and future graduate students to consider - I hope the following book list will provide a solid base of recent scholarship for those wishing to broaden their understanding of the history of work and labor in the first non-Western industrialized nation.

By a quick survey of titles in this list, most readers easily will recognize many tropes made standard by scholarship on labor in Europe, Australia and the USA. Not all the books selected, however, necessarily fall into the conventional rubric of labor history. James Roberson's and Nobue Suzuki's Men and Masculinity in Contemporary Japan, for example, is an edited collection of essays examining the extent to which popular notions of the Japanese 'salaryman' have over-determined how many Japanese men themselves think of their lives as male while-collar workers and family men. Yuko Ogasawara's Office Ladies and Salaried Men, however, examines the extent to which pink-collar workers navigate a workplace structured to discourage their advancement by acollectively working (in a distinctly white-collar variation on John Scott's theory of peasant foot-dragging) to bolster, or undermine, the careers of the salaryman generally credited with Japan's postwar economic success.

Readers also will note the number of works on women and labor. This is in part the result of my particular interests as a labor historian and also is due to a specific trend in English language studies of Japanese labor since 1990. Indeed, the past 15 years of scholarship have shown how the story of industrialization in Japan can be told through the experiences of the wage-earning women who, until 1930, comprised the majority of Japan's factory workers. This list starts and ends with works on female textile workers, and I think there is no better way to understand the history of work and labor in Japan as well as the trajectory taken by scholars in the field.

*Email: cgerteis@gmail.com 
Managing Women: Disciplining Labor in Modern Japan, by Elyssa Faison, Berkeley, University of California Press, 2007, ISBN 9780520252967

Shifting Boundaries of the Firm: Japanese Company-Japanese Labour, by Mari Sako, Oxford, Oxford University Press, 2006, ISBN 0199268169

The Embedded Corporation: Corporate Governance and Employment Relations in Japan and the United States, by Sanford M Jacoby, Princeton, NJ, Princeton University Press, 2005, ISBN 0691119996

A Sociology of Work in Japan, by Ross E. Mouer and Hirosuke Kawanishi, Cambridge, Cambridge University Press, 2005, ISBN 9780521651202

Divisions of Labor: Globality, Ideology, and War in the Shaping of the Japanese Labor Movement, by Lonny E. Carlile, Honolulu, University of Hawai'i Press, 2005, ISBN 0824824563

Labor Contracts and Labor Relations in Early Modern Central Japan, by Mary Louise Nagata, London, RoutledgeCurzon, 2005, ISBN 0415346053

Globalization and Women in the Japanese Workforce, by Beverley Bishop, London, Routledge, 2004, ISBN 9780415342490

Men and Masculinities in Contemporary Japan: Dislocating the Salaryman Doxa, edited by James E Roberson and Nobue Suzuki, London, Routledge, 2003, ISBN 0415271479

Women's Employment in Japan: The Experience of Part-Time Workers, by Kaye Broadbent, London, RoutledgeCurzon, 2003, ISBN 978070071749

Struggle and Purpose in Postwar Japanese Unionism, by Michael H. Gibbs, Berkeley, Institute of East Asian Studies, 2000, ISBN 1557290660

Office Ladies and Salaried Men: Power, Gender, and Work in Japanese Companies, Yuko Ogasawara, Berkeley, University of California Press, 1998, ISBN 9780520210448

Disparaged Success: Labor Politics in Postwar Japan, by Ikuo Kume, Ithaca, NY, Cornell University Press, 1998, ISBN 0801433649

The Wages of Affluence: Labor and Management in Postwar Japan, by Andrew Gordon, Cambridge, MA, Harvard University Press, 1998, ISBN 0674805771

Creating Socialist Women in Japan: Gender, Labour, and Activism, 1900-1937, by Vera C. Mackie, Cambridge, Cambridge University Press, 1997, ISBN 9780521551373

Portraits of the Japanese Workplace: Labor Movements, Workers, and Managers, by Makoto Kumazawa, Boulder, CO, Westview Press, 1996, ISBN 9780813317083

Japanese Workers in Protest: An Ethnography of Consciousness and Experience, by Christina L. Turner, Berkeley, University of California Press, 1995, ISBN 9780520085701

Nightwork: Sexuality, Pleasure, and Corporate Masculinity in a Tokyo Hostess Club, by Anne Allison, Chicago, University of Chicago Press, 1994, ISBN 9780226014876

Staying on the Line: Blue-Collar Women in Contemporary Japan, by Glenda Susan Roberts, Honolulu, University of Hawai'i Press, 1994, ISBN 0824815793 
Women and the Economic Miracle: Gender and Work in Postwar Japan, by Mary C. Brinton, Berkeley, University of California Press, 1994, ISBN 9780520089204

Japanese Women Working, by Janet Hunter, London, Routledge, 1995, ISBN 9780415127912

Industrial Harmony in Modern Japan: the Invention of a Tradition, by William Dean Kinzley, London, Routledge, 1991, ISBN 9780415051675

Labor and Imperial Democracy in Prewar Japan, by Andrew Gordon, Berkeley, University of California Press, 1991, ISBN 9780520067837

Crafting Selves: Power, Gender, and Discourses of Identity in a Japanese Workplace, by Dorinne K. Kondo, Chicago, University of Chicago Press, 1990, ISBN 9780226450445

Factory Girls: Women in the Thread Mills of Meiji Japan, by E. Patricia Tsurumi, Princeton, NJ, Princeton University Press, 1990, ISBN 9780691000350

\section{Notes on contributor}

Christopher Gerteis is an historian of modern and contemporary Japan specializing in the history of labor and gender since 1945. He is presently finishing a book manuscript examining the intersection of work, citizenship, and gender in postwar Japan. He is an Assistant Professor of East Asian History at Creighton University, Omaha (NE). 